\title{
The Importance of Teaching Assistant Support and Interactions in Student Engagement
}

\author{
Denise Wilson \\ Department of Electrical and Computer Engineering, \\ University of Washington
}

Box 352500

Seattle, Washington, USA 98195-2500

denisew@uw.edu; 206-221-5238

Joanna Wright and Lauren Summers

College of Education, University of Washington

Box 3533600

Seattle, Washington USA 98195-3600

\begin{abstract}
Prior research on the impact of instructors on student engagement has focused primarily on faculty, but teaching assistants (TAs) are also important. This study examined relationships among TA support, TA-student interactions, and student engagement and also sought to identify groups of students for whom TA support and TA-student interactions appeared particularly important. Hierarchical linear regression models using cross-sectional survey data from over 750 students at a single large public institution were used to assess relationships between TA support, TA-student interactions, and three forms of student behavioral engagement. TA support positively and significantly predicted all engagement variables. For effort and participation, TA-student interactions positively and significantly predicted engagement while for attention, this relationship was significant but negative. Some interaction effects involving gender, race, mother's education, and U.S. status were also significant. Our findings underscored the importance of TAs in the student academic experience.
\end{abstract}

\section{Keywords}

engagement; graduate teaching assistant; motivation; academic support, academic integration 


\section{Introduction}

Teaching Assistants (TAs) play significant roles in undergraduate instruction in the United States. In 2017, the Bureau of Labor Statistics estimated that 131,490 graduate students were employed as teaching assistants in the United States, and of these, 126,340 individuals were employed at colleges, universities, and professional schools, comprising $4.15 \%$ of the university workforce (Bureau of Labor Statistics, n.d.). In undergraduate engineering courses, TAs perform a wide variety of tasks including lecturing, leading lab sections, conducting review sessions, facilitating discussions, holding office hours, and providing technological support. In some fields like biology, TAs teach over $90 \%$ of lab sections at research universities (Gardner \& Jones, 2011). Many of these lab sections are associated with first- or second-year courses and are seen as "gateway" courses, which are required for students entering science and engineering majors and in which attrition rates are especially high (O'Neal et al., 2007; Seymour \& Hewitt, 2000). In these courses, students frequently have more overall contact with their TAs than with professors, and TAs are therefore a "first line of defense" in instruction, profoundly influencing the effectiveness of faculty and departments in which they serve (Gardner \& Jones, 2011; Rushin et al., 1997).

By examining connections between undergraduate student engagement and TA support and TAstudent interactions, this study focuses on the critical and unique roles that TAs play in undergraduate instruction in engineering.

\section{Background -- TAs}

Given the importance of TAs in STEM education, evidence that TAs and other contingent instructors were less effective than tenure track faculty in teaching undergraduates is concerning (Umbach, 2007). However, previous research has indicated that undergraduates perceive TAs differently than regular faculty, suggesting that TAs may have a different impact on student engagement and learning than faculty do. While students viewed faculty as experienced, organized, and confident but also as strict, boring, and distant, they viewed TAs as interactive, engaging, understanding, and relatable but also uncertain and less confident (Kendall \& Schussler, 2012). These significant differences in perception likely led to differences in how students interacted with and engaged with TAs compared to faculty. Thus, the faculty support literature is limited in providing insight into how TA support and TA-student interactions are assocaited with student learning and engagement.

Most studies of engineering and other STEM TAs have focused on TA background characteristics, experiences, and training (e.g. Gardner \& Jones, 2011; Prieto \& Altmaier, 1994; Reeves et al., 2016; Shannon et al., 1998). While not as numerous as studies of faculty support, studies that specifically focused on TA support nevertheless reaffirmed its importance. For example, in biology courses, TAs provided a level of personalization and enjoyment for students that complemented the more aloof, authoritative, and strict control that undergraduates perceived of instructional faculty (Kendall \& Schussler, 2012). A similar study of high-enrollment biology courses at a research-intensive Australian university (Good et al., 2015) found that consistent TAstudent pairings enabled mentoring relationships to develop and contributed to gains in student motivation and learning. 
Mentoring and other relational support has often expressed via one-on-one interactions between TAs and students. While the benefit of student-faculty interaction for student engagement has been well established by prior literature (Umbach \& Wawrzynski, 2005), examination of this effect among TAs and students has been more limited. A study of physics tutorials found that a majority of interactions were initiated by TAs, underscoring the importance of their investment in student experience and engagement (Scherr et al., 2006). The number of times that a TA initiated such interactions with a student as well as the total frequency of interactions were associated with positive student evaluations (Hazari et al., 2003) and student engagement (Scherr et al., 2006, 2006) in physics laboratories. TA-student interactions were also associated with positive student perceptions of their own learning (Wheeler et al., 2017).

Other relational support provided by TAs may also inform student learning and satisfaction. For example, the perception of how amiable, calm, and clear a TA is shaped student satisfaction in laboratory courses in physics (Hazari et al., 2003). In project-based learning in engineering, TAs also played a critical role by providing the relatedness needed to advance competence beyond what was possible in courses with more traditional structure. In contrast, a lack of concern by the TA for student learning or lack of connection between TA and student impaired gains in competence and reduced motivation (Trenshaw et al., 2016). In gateway science courses, TAs impacted lab climate (i.e. how fun and welcoming a lab is), course grades, and student understanding of science careers, which in turn can impact persistence and retention (O’Neal et al., 2007).

This body of literature has underscored the importance of TAs in contributing to student learning but it has also highlighted the different roles that TAs play in student learning compared to regular faculty. This study builds on the limited literature that focuses specifically on TAs by looking at relationships between the types of academic support and interactions TAs provide and student engagement in academic courses.

\section{Background -- Engagement}

Student engagement is typically understood to capture the time and effort students give to college activities that lead to positive outcomes, as well as what higher education institutions do to involve students in such activities (Kuh, 2009). Wolf-Wendel et al. (2009) pointed out that engagement is often viewed as potentiating integration. Students become integrated by becoming engaged, being involved, and expending effort that results in positive outcomes.

Student engagement in college life, both social and academic, has been connected to many positive academic outcomes including gains in critical thinking skills (Carini et al., 2006; Gellin, 2003), GPA (Carini et al., 2006), and exam and homework grades (Handelsman et al., 2005). Conversely, lower engagement has been consistently related to withdrawal from college (Hughes \& Pace, 2003). And, indirectly, academic and social engagement have been associated with gains in learning through the integration of information (Pike \& Killian, 2001). Furthermore, engagement has been shown to have an especially important "compensatory effect" (Kuh et al., 2008, p. 555) for some groups of first-year students, including students of color and students entering college with lower levels of academic preparation (Kuh et al., 2008).

While significant, the relationships between different forms of engagement and academic 
outcomes can nevertheless vary widely in strength. For example, in a comprehensive study by Carini et al. (2006), the effort (i.e. a form of behavioral engagement) put forth by students in completing readings and assignments was strongly correlated to standardized test scores. But, working with other students on projects during class was not correlated to learning at all, and preparing two or more drafts of papers was more weakly correlated with learning. A meta-analysis by Robbins (Robbins et al., 2004) of psychosocial and study skills confirmed the importance of class-related behavior in that the effort students put into homework assignments and preparing for tests was moderately related to retention, and the motivation to achieve was strongly related to retention. Another study that focused on developing measures of engagement for specific courses demonstrated more consistent positive associations with academic outcomes than those which study engagement more broadly (Handelsman et al., 2005).

In combination, these studies support the need to examine engagement in specific contexts. This study looks at the specific contexts of large undergraduate courses that rely heavily on TAs to support student learning in order to explore the impacts TAs have on student engagement. In addition to studying engagement at an external behavioral level (via participation), this study also considers internally motivated engagement reflected in the attention and effort that students feel they put forth in their studies. Motivational measures have been identified as having strong associations with self-regulated learning behaviors and learning outcomes (Connell \& Wellborn, 1991; Deci et al., 1991) and are as important as time-on-task measures such as participation.

\section{Conceptual Framework}

Our investigation of TA contributions to student engagement is informed by multiple models of student and teaching success in higher education. Tinto's (1993) model of student persistence frames student outcomes as arising out of a dynamic interplay between personal and institutional characteristics (Tinto, 1986) and involving both students' academic and social integration with the institution. Previous studies building on Tinto's work have underscored the important contributions that instructors make to student integration (Wolf-Wendel et al., 2009). As instructors, TAs are likely to contribute to students' academic integraiton. Further, since TAs are viewed as more interactive and relatable than regular faculty (Kendall \& Schussler, 2012), they are also likely to play a stronger role in students' social integration than regular faculty. While integration is a distinct construct, it has been strongly related to engagement on multiple levels (Kamphorst et al., 2015). Engagement is also impacted by student demographics such as gender and race/ethnicity and incoming student characteristics such as socioeconomic status and parents' education. Astin's Inputs-Environments-Outcomes model assesses how these demographics interact with institutional practices including faculty-student interactions and faculty support in influencing behavioral, psychological, affective, and cognitive outcomes including student engagement. And while the instructional practices that students value share common elements of good teaching, some forms of support vary between disciplines. Therefore, to study TA support in engineering, we two of these common elements: (a) frequent student-teacher contact and (b) prompt feedback (Chickering \& Gamzon, 1987) and also practices that are especially important to engineering and other physical sciences. These discipline-specific practices include establishing the relevance of course material through the use of real-world examples and the formulation of clear, objective, and organized instructional goals (Felder, 2000). 


\section{Research Questions}

Our research sought to understand how TA support and TA-student interactions are related to student engagement in engineering courses. Two research questions guided our analysis:

\section{Research Question \#1 (RQ1):}

Are TA Support and TA-student interactions significantly related to student engagement? Previous studies of how TAs influence student engagement in STEM including engineering have been largely limited to laboratory sections and observable measures of engagement. This study adds to that work by exploring multiple learning environments in which TAs operate (e.g. recitations, discussion sections, labs) and digging deeper into student engagement by using student self-reports of an observable measure of engagement (participation) and two motivational measures of engagement (attention and effort).

\section{Research Question \#2 (RQ2):}

Do different students appear to respond to TA support and TA-student interactions differently? Prior research has shown that instructor support can impact different groups of students in distinct ways and that this holds true for engineering and other STEM undergraduate settings (Hurtado et al., 2011; Seymour \& Hewitt, 2000). This study expands on this notion by evaluating which demographic variables interact with TA support or TA-student interactions in relation to the three forms engagement studied here.

\section{Research Methods}

This study is based on a survey that was specifically designed to measure TA support, TA-student interactions, and student engagement. The study was conducted at a single large public university classified as a doctoral university with very high research activity (Carnegie Foundation, 2018). Class enrollment in the courses surveyed ranged from 60 to 250 students. Multiple TAs supported each course. Most TAs were graduate students, but some were undergraduate students. The majority of TAs were Asian, and most were male. In addition to standard background variables of race and gender, student demographic questions related to socioeconomic status, including family income, mother's education, father's education, and socioeconomic class, were also collected. Due to small sample sizes, minority racial groups were consolidated into two groups: Black and other (non-Black) under-represented minorities (URM). The latter group included Pacific Islander, American Indian, Alaska Native, and other racial groups that were not Asian, Black, or White. The largest populations of students in the sample population were male (74.9\%), Asian (45.7\%), mid-income (40.3\%), domestic (81.0\%), or native, non-transfer $(72.7 \%)$. Detailed demographics describing the survey population are summarized in Table 1. 
Table 1: Survey Participant Demographics $(N=781)$

\begin{tabular}{|c|c|c|c|}
\hline Demographic & \multicolumn{3}{|c|}{ Group: $\mathbf{N}(\%)^{*}$} \\
\hline Gender & Males: 585 (74.9\%) & Females: $184(23.6 \%)$ & \\
\hline Race & $\begin{array}{l}\text { Asian: } 357(45.7 \%) \\
\text { Black: } 27(3.5 \%)\end{array}$ & $\begin{array}{l}\text { Caucasian/White: } 311 \text { (39.8\% } \\
\text { Other (non-Black) URM: } 67\end{array}$ & \\
\hline Family Income & $\begin{array}{l}\text { Low Income }(<\$ 40 \mathrm{k} / \mathrm{yr}) \text { : } \\
142(18.2 \%)\end{array}$ & $\begin{array}{l}\text { Mid Income }(\$ 40 \mathrm{k}-\$ 100 \mathrm{k} / \mathrm{yr}) \text { : } \\
315(40.3 \%)\end{array}$ & $\begin{array}{l}\text { High Income }(>\$ 100 \mathrm{k} / \mathrm{yr}) \\
259(33.2 \%)\end{array}$ \\
\hline $\begin{array}{l}\text { Mother's } \\
\text { Education }\end{array}$ & $\begin{array}{l}\text { No Degree: } \\
189(24.2 \%)\end{array}$ & $\begin{array}{l}\text { AA, AS, BS, BA Degree: } \\
391(50.1 \%)\end{array}$ & $\begin{array}{l}\text { Graduate Degree: } \\
185(23.7 \%)\end{array}$ \\
\hline U.S. Status & $\begin{array}{l}\text { U.S. Citizen/ Permanent } \\
\text { Resident: } 633(81.0 \%)\end{array}$ & $\begin{array}{l}\text { International Student: } \\
137(17.5 \%)\end{array}$ & \\
\hline Delay to Entry & $\begin{array}{l}\text { Native (Non-Transfer): } \\
568(72.7 \%)\end{array}$ & $\begin{array}{l}\text { Transfer: } \\
195(25.0 \%)\end{array}$ & \\
\hline
\end{tabular}

* Percentages within a demographic group may not add up to $100 \%$ because not all participants responded.

\section{Procedures}

Students from seven different sophomore-level engineering courses (four in electrical and computer engineering, three in mechanical engineering) were recruited between Fall 2016 and Spring 2018 to complete a survey about the course in which they were enrolled. The instructor for each course was given the choice of offering the survey to students in paper-and-pencil or electronic form. Students in one course were offered the paper-and-pencil version and completed this version in class. Students in the other six courses were offered the electronic version and completed it outside of class.

Participation in the study was voluntary. Student consent was obtained for all survey participants. At the discretion of the instructor, students were offered an incentive for completing the survey, which was usually a form of extra credit in the course. 781 students completed the survey, representing $85 \%$ of students enrolled overall in the seven courses and between $30 \%$ and $91 \%$ of students in each course, with no duplications (i.e. no student was enrolled in more than one of the courses studied).

Preliminary analyses demonstrated significant bivariate Pearson correlations (greater than 0.6) between mother's education and father's education. Further, preliminary one-way analyses of variance (ANOVA) demonstrated significant differences in engagement $(p<0.05)$ among groups by mother's education, but not by father's education. Therefore, only mother's education was retained for the regression models. Because family income and socioeconomic class had a bivariate Pearson correlation of 0.6 , socioeconomic status was also discarded from the regression models while family income level was retained.

U.S. and transfer status were also included in the regression models based on Tinto's model of 
student integration (Tinto, 1993) which indicates that students' past educational experiences lead to differences in student integration into higher education institutions. Transferring from a community college, working for a significant period of time between high school and university, and attending high school in another country represent major differences in students' past educational experiences compared with students who transition directly from a U.S. high school into university. Thus, they are likely to influence how, when, and why students engage differently than majority populations of students.

\section{Measures}

The dependent variables used in this analysis were based on three forms of engagement: attention, effort, and participation. All engagement scales used items that were adapted for use in higher education (Wilson et al., 2015) from previous studies in K-12 (Miserandino, 1996). All engagement items were assessed using a 5-point Likert scale ranging from 1 (strongly disagree) to 5 (strongly agree). The original scales measuring the three forms of engagement have demonstrated adequate internal consistency and construct validity. Sample items for each engagement scale are provided in Table 2.

Table 2: Engagement (Dependent) Variables

Primary Scale Sample Item

Attention $(\alpha=0.83) \quad$ When I'm in this class, my mind wanders.

Effort $(\alpha=0.78) \quad$ I try hard to do well in this class.

Participation $(\alpha=0.64)$

In this class, I participate in class discussions

during lecture with my classmates and instructors.

Attention measures to what extent students are thinking about other things besides the topics at hand in their classes. Effort evaluates how hard students try to work in their classes and lab/study groups. Participation measures how students view their participation in class discussions. Although in this dataset, participation had an internal reliability of less than the standard 0.7 , there is evidence that reliability between 0.6 and 0.7 is adequate (George \& Mallery, 2010). Therefore, participation was retained for analysis.

Two independent variables emerged from this study based on an exploratory factor analysis of 21 items (Table 3) that were either adapted from previous studies of faculty support and facultystudent interactions or observations of TA-led classrooms in engineering. These 21 items included four items adapted from teaching practices in the National Survey of Student Engagement (2019), five items adapted from the teacher academic support subscale developed by Van Ryzin et. al. (2009), and six items adapted from the faculty contact scale used by Einarson and Clarkberg (2010). An additional six items were also formulated based on observations of TA-led classrooms and interactions with students in a previous study (Wright et al., 2019). 
Table 3: TA Items

\begin{tabular}{|c|c|c|}
\hline Adapted from & Label & Item \\
\hline \multirow{4}{*}{ Teaching Practices } & TP1.1 & $\begin{array}{l}\text { At least one of the TAs or secondary instructors in this class has clearly } \\
\text { explained course goals and requirements. }\end{array}$ \\
\hline & TP1.2 & $\begin{array}{l}\text { At least one of the TAs or secondary instructors in this class often } \\
\text { teaches in an organized way. }\end{array}$ \\
\hline & TP1.3 & $\begin{array}{l}\text { At least one of the TAs or secondary instructors in this class often uses } \\
\text { real-world examples or illustrations to explain difficult points. }\end{array}$ \\
\hline & TP1.4 & $\begin{array}{l}\text { At least one of the TAs or secondary instructors in this class has often } \\
\text { provided feedback on a draft or work/homework in progress. }\end{array}$ \\
\hline \multirow{5}{*}{ Academic Support } & AS1.1 & $\begin{array}{l}\text { At least one of the TAs or secondary instructors in this class is willing } \\
\text { to spend time outside of class to discuss issues that are of interest and } \\
\text { importance to me. }\end{array}$ \\
\hline & AS1.2 & $\begin{array}{l}\text { At least one of the TAs or secondary instructors in this class is } \\
\text { interested in helping me learn. }\end{array}$ \\
\hline & AS1.3 & $\begin{array}{l}\text { At least one of the TAs or secondary instructors in this class cares about } \\
\text { how much I learn. }\end{array}$ \\
\hline & AS1.4 & $\begin{array}{l}\text { At least one of the TAs (or secondary instructors) in this class treats me } \\
\text { with respect. }\end{array}$ \\
\hline & AS1.5 & $\begin{array}{l}\text { At least one of the TAs (or secondary instructors) in this class is } \\
\text { available when I need help. }\end{array}$ \\
\hline \multirow{6}{*}{ Faculty Contact } & FC1.1 & $\begin{array}{l}\text { I have discussed career plans with at least one of the TAs or secondary } \\
\text { instructors in this class. }\end{array}$ \\
\hline & $\mathrm{FC} 1.2$ & $\begin{array}{l}\text { I have discussed academic work with at least one of the TAs or } \\
\text { secondary instructors in this class. }\end{array}$ \\
\hline & $\mathrm{FC} 1.3$ & $\begin{array}{l}\text { I have had intellectual discussions outside of academic work with at } \\
\text { least one of the TAs or secondary instructors in this class. }\end{array}$ \\
\hline & $\mathrm{FC} 1.4$ & $\begin{array}{l}\text { I have discussed course selection with at least one of the TAs or } \\
\text { secondary instructors in this class. }\end{array}$ \\
\hline & $\mathrm{FC} 1.5$ & $\begin{array}{l}\text { I have socialized with at least one of the TAs or secondary instructors } \\
\text { in this class. }\end{array}$ \\
\hline & $\mathrm{FC} 1.6$ & $\begin{array}{l}\text { I have discussed my academic performance with at least one of the TAs } \\
\text { or secondary instructors in this class. }\end{array}$ \\
\hline \multirow{6}{*}{ TA Observations } & Obs1.1 & $\begin{array}{l}\text { The TA for my }<\text { recitation or lab }>\text { section in this class often arrives at } \\
\text { least five minutes before section begins. }\end{array}$ \\
\hline & Obs1.2 & $\begin{array}{l}\text { The TA for my }<\text { recitation or lab }>\text { section in this class often stays after } \\
\text { class to answer questions. }\end{array}$ \\
\hline & Obs 1.3 & $\begin{array}{l}\text { The TA for my }<\text { recitation or lab }>\text { section in this class often stops to } \\
\text { ask questions during section. }\end{array}$ \\
\hline & Obs1.4 & $\begin{array}{l}\text { The TA for my }<\text { recitation or lab }>\text { section in this class is often funny } \\
\text { or interesting. }\end{array}$ \\
\hline & Obs1.5 & $\begin{array}{l}\text { I have attended office hours to see at least one of the TAs or secondary } \\
\text { instructors in this class. }\end{array}$ \\
\hline & Obs1.6 & $\begin{array}{l}\text { I have e-mailed at least one of the TAs or secondary instructors in this } \\
\text { class for assistance. }\end{array}$ \\
\hline
\end{tabular}




\section{Data Analysis}

Student survey data were analyzed using SPSS 19 to perform preliminary analyses, conduct exploratory factor analyses of the TA items to identify suitable independent variables, and to construct the hierarchical linear regression models that were used to examine the two research quesitons in this study.

Preliminary analyses computed descriptive statistics, evaluated skewness and kurtosis of the engagement variables, computed the reliability of the TA scales, conducted preliminary analyses of variance (ANOVA), computed Pearson bivariate correlations, and constructed null mixed (hierarchical linear or HLM) models. Skewness and kurtosis of the engagement variables were computed to confirm variable normality. Results indicated that all three engagement variables were sufficiently normally distributed to proceed with analysis (George \& Mallery, 2010). Pearson bivariate correlations between pairs of engagement variables were all below .5. Therefore, all three engagement variables were retained.

To identify appropriate TA support and TA-student interactions scales, an exploratory factor analysis (EFA) was conducted using varimax rotation. The number of factors was initially determined by an eigenvalue threshold of 1 while also considering the point at which the scree plot for the eigenvalues levelled off and adding additional factors no longer explained variance in the data. Items that demonstrated communalities of less than 0.5 and failed to demonstrate a strong $(>0.6)$ loading on any single factor were discarded. Items that loaded onto more than one factor $(>0.4)$ were also discarded. After items were discarded, any remaining factors containing at least two items were retained for analysis.

Using the TA support and TA-student interaction scales that emerged from EFA, a mixed model using HLM (hierarchical linear modelling) was constructed to understand whether nesting of students within TA sections and within courses affected the engagement variables. The results of a null HLM model (i.e. one that did not contain the independent variables) confirmed that the variance contributed to both forms of engagement at the TA level and course level was not significant. Thus, the results of hierarchical regression were unlikely to be confounded by nesting effects, making this approach to data analysis appropriate for this data.

After these preliminary analyses, a series of hierarchical regression models were used to examine the degree to which demographics, TA support, and TA-student interactions predicted the three forms of engagement. TA support and TA-student interactions were all standardized prior to inserting them into the models in order to reduce multicollinearity when interaction terms were introduced. Preliminary regression models using demographic characteristics and the TA behavior scales were used to identify potential interactions of interest. Demographic characteristics were effect coded in the regression models as follows:

- Gender $($ male $=-1$; female $=1)$ : other genders were present in very small numbers and were eliminated from the analysis.

- Race (White or Asian =-1 -1; Black = 10 ; other URM = 0 1): the two variables used to represent race were labeled race (Black) and race (non-Black URM). 
- Family income (between $\$ 20,000 /$ year and $\$ 80,000 /$ year $=-1-1$; less than $\$ 20,000 / y r=01$; more than $\$ 80,000 / \mathrm{yr}=10$ ): the two variables used to represent family income were labelled family income (high) and family income (low).

- Mother's education (AA, AS, BS, or BA $=-1-1$; a graduate degree (e.g. MS, $\mathrm{PhD}, \mathrm{JD})=0$ 1; no degree $=10$ ): the two variables used to represent family income were labelled mother (no degree) and mother (grad degree).

- U.S. citizenship (U.S. citizen or permanent resident $=-1$; international student $=1$ ): this variable was labelled U.S. status.

- Transfer students (native or non-transfer $=-1$; transfer $=1$ ): students who began college at the institution in this study at the same time as beginning college altogether were coded as nontransfer. All other students were designated transfer.

Initially, each model considered all possible interactions between the demographic variables and the TA behavior scales. The model was then reduced by eliminating the interaction with the highest $p$-value, one interaction at a time until only significant interactions remained. The Bayesian (BIC) criterion was also calculated and considered in selecting the most parsimonious model for analysis. A reduced model that included significant interactions but also resulted in the lowest BIC was retained for interpretation.

\section{Results}

The results of the EFA of the $21 \mathrm{TA}$ iterms are summarized in Table 4. Three factors with eigenvalues greater than 1 emerged from the EFA of these items, but only two factors contained items with loadings and cross-loadings sufficient to retain the factors for analysis. The first factor included a combination of the teaching practices, academic support, and observations of TA teaching practice and was labelled TA support. This scale was retained for subsequent analyses and demonstrated a reliability (Cronbach's alpha) of 0.921 . It is noteworthy that items related to what the TA was doing (e.g. being organized, asking questions) and what the students perceived the TA felt about what they were doing (e.g. cared and was interested in helping the students learn) loaded onto the same factor.

For the second factor, four of the original six items from the faculty contact scale had loadings of greater than 0.8 onto Factor 2 but did not load onto any other factors. One observation item (Obs 1.6) which asked students to report how often they had contacted a TA by e-mail for assistance also loaded cleanly onto Factor 2. Thus, these five items were retained into a single scale called TA-student interactions with a reliability (Cronbach's alpha) of 0.924 . 
Table 4: Factor Loadings for TA Support Items

\begin{tabular}{|c|c|c|c|c|c|}
\hline Item & Factor 1 & Factor 2 & Factor 3 & Communality & TA Behavior Measure \\
\hline TP 1.1 & 0.744 & 0.128 & -0.016 & 0.561 & \multirow{9}{*}{ TA support } \\
\hline TP 1.2 & 0.816 & 0.096 & 0.103 & 0.687 & \\
\hline TP 1.3 & 0.638 & 0.214 & 0.026 & 0.445 & \\
\hline TP 1.4 & 0.640 & 0.059 & 0.254 & 0.472 & \\
\hline AS 1.1 & 0.735 & 0.139 & 0.172 & 0.561 & \\
\hline AS 1.2 & 0.795 & 0.126 & 0.169 & 0.687 & \\
\hline AS 1.3 & 0.790 & 0.135 & 0.155 & 0.666 & \\
\hline AS 1.4 & 0.745 & -0.038 & 0.225 & 0.608 & \\
\hline AS 1.5 & 0.610 & -0.005 & 0.235 & 0.428 & \\
\hline FC 1.1 & 0.104 & 0.880 & 0.139 & 0.807 & TA-student interactions \\
\hline FC 1.2 & 0.162 & 0.521 & 0.584 & 0.639 & discarded \\
\hline FC 1.3 & 0.164 & $\mathbf{0 . 8 5 7}$ & 0.117 & 0.775 & \multirow{2}{*}{ TA-student interactions } \\
\hline FC 1.4 & 0.113 & 0.858 & 0.132 & 0.766 & \\
\hline FC 1.5 & 0.280 & 0.429 & 0.617 & 0.643 & discarded \\
\hline FC 1.6 & 0.102 & 0.845 & 0.223 & 0.773 & TA-student interactions \\
\hline Obs 1.1 & 0.611 & 0.094 & -0.151 & 0.405 & \multirow{4}{*}{ TA support } \\
\hline Obs 1.2 & 0.703 & 0.089 & 0.064 & 0.507 & \\
\hline Obs 1.3 & 0.682 & 0.180 & -0.042 & 0.500 & \\
\hline Obs 1.4 & 0.749 & 0.244 & 0.111 & 0.632 & \\
\hline Obs 1.5 & 0.093 & 0.322 & 0.805 & 0.760 & discarded \\
\hline Obs 1.6 & 0.102 & 0.845 & 0.223 & 0.545 & TA-student interactions \\
\hline
\end{tabular}

Descriptive statistics for TA support and TA-student interactions as well as the three engagement measures (attention, effort, participation) are summarized in Table 5. All measures were scaled to values between 1 and 5 .

Table 5: Descriptive Statistics

$\begin{array}{lccccc} & \text { TA support } & \begin{array}{c}\text { TA-student } \\ \text { interactions }\end{array} & \text { Attention } & \text { Effort } & \text { Participation } \\ N & 696 & 755 & 762 & 765 & 736 \\ \text { Mean } & 3.56 & 1.58 & 2.76 & 3.88 & 3.21 \\ \text { Standard Deviation } & 0.78 & 0.87 & 0.99 & 0.79 & 0.95 \\ \text { Maximum } & 5.00 & 5.00 & 5.00 & 5.00 & 5.00 \\ \text { Minimum } & 1.08 & 1.00 & 1.00 & 1.00 & 1.00\end{array}$

\section{Engagement Models}

A three-level regression model was constructed for each engagement variable. Model 1 contained 
all nine demographic variables, effect coded as described previously. Model 2 contained TA support and TA-student interactions, and Model 3 contained interactions that were associated with the most parsimonious regression model for each form of engagement.

Table 6: Summary of Linear Regression Models for Engagement

\begin{tabular}{|c|c|c|c|}
\hline & Model 1 & Model 2 & Model 3 \\
\hline \multirow[t]{2}{*}{ Attention } & $\begin{array}{l}\mathrm{R}^{2}=0.036 \\
\Delta \mathrm{R}^{2}=0.042 \\
\text { Adjusted } \mathrm{R}^{2}=0.042 \\
\mathrm{SE}=0.972 \\
\Delta \mathrm{F}=2.30^{*}\end{array}$ & $\begin{array}{l}\mathrm{R}^{2}=0.072 \\
\Delta \mathrm{R}^{2}=0.036 \\
\text { Adjusted } \mathrm{R}^{2}=0.053 \\
\mathrm{SE}=0.956 \\
\Delta \mathrm{F}=10.6^{* * *}\end{array}$ & $\begin{array}{l}\mathrm{R}^{2}=0.111 \\
\Delta \mathrm{R}^{2}=0.040 \\
\text { Adjusted } \mathrm{R}^{2}=0.089 \\
\mathrm{SE}=0.938 \\
\Delta \mathrm{F}=8.18^{* * *}\end{array}$ \\
\hline & $\begin{array}{l}\text { Interactions: } \\
\text { gender X TA support }\end{array}$ & ack) X TA support; U & TA-student interactions \\
\hline \multirow[t]{2}{*}{ Effort } & $\begin{array}{l}\mathrm{R}^{2}=0.026 \\
\Delta \mathrm{R}^{2}=0.026 \\
\text { Adjusted } \mathrm{R}^{2}=0.011 \\
\mathrm{SE}=0.808 \\
\Delta \mathrm{F}=1.67\end{array}$ & $\begin{array}{l}\mathrm{R}^{2}=0.117 \\
\Delta \mathrm{R}^{2}=0.091 \\
\text { Adjusted } \mathrm{R}^{2}=0.099 \\
\mathrm{SE}=0.771 \\
\Delta \mathrm{F}=28.3 * * *\end{array}$ & $\begin{array}{l}\mathrm{R}^{2}=0.133 \\
\Delta \mathrm{R}^{2}=0.016 \\
\text { Adjusted } \mathrm{R}^{2}=0.114 \\
\mathrm{SE}=0.765 \\
\Delta \mathrm{F}=10.2 * *\end{array}$ \\
\hline & Interactions: U.S. sta & A support & \\
\hline \multirow[t]{3}{*}{ Participation } & $\begin{array}{l}\mathrm{R}^{2}=0.050 \\
\Delta \mathrm{R}^{2}=0.050 \\
\text { Adjusted } \mathrm{R}^{2}=0.035 \\
\mathrm{SE}=0.952 \\
\Delta \mathrm{F}=3.28^{* *}\end{array}$ & $\begin{array}{l}\mathrm{R}^{2}=0.288 \\
\Delta \mathrm{R}^{2}=0.238 \\
\text { Adjusted } \mathrm{R}^{2}=0.274 \\
\mathrm{SE}=0.822 \\
\Delta \mathrm{F}=94.2 * * *\end{array}$ & $\begin{array}{l}\mathrm{R}^{2}=0.296 \\
\Delta \mathrm{R}^{2}=0.008 \\
\text { Adjusted } \mathrm{R}^{2}=0.281 \\
\mathrm{SE}=0.821 \\
\Delta \mathrm{F}=6.10^{*}\end{array}$ \\
\hline & Interactions: mother & ree) X TA support & \\
\hline & $* \mathrm{p}$ & $* \mathrm{p}<0.01 ; * * * \mathrm{p}<0$ & \\
\hline
\end{tabular}

In all three engagement regressions (Table 6), the independent variables (demographic characteristics) used in the first level of each model explained little of the variance in the data (3.6\%, 2.6\% and 5.0\% for attention, effort and participation respectively). Including TA support and TA-student interactions in Model 2 substantially strengthened each of the models. The twolevel models explained $7.2 \%, 11.7 \%$, and $28.8 \%$ of the variance in the data for attention, effort, and participation respectively.

\section{Attention}

The regression models for attention are summarized in Table 7. Being an international student consistently, significantly, and positively predicted attention. No other demographic variables predicted attention once TA support and TA-student interactions were considered (Model 2). Both TA support and TA-student interactions significantly predicted attention. However, the regression coefficient for TA support was positive $(\mathrm{p}<0.01)$ while that for $T A$ contact was negative $(\mathrm{p}<0.001)$.

Only three interactions remained significant in the process of iteratively reducing the model to its most parsimonious form. As a result of the reduction, the BIC decreased to 7.30 (only three 
interactions considered) from 87.7 when all 18 interactions were considered and 13.0 when no interactions were considered. Interactions between gender and TA support, race and TA support, and U.S. status and TA-student interactions were all significant. The attention reported by women increased more with increasing TA support than for men (Figure 1). Attention reported by black students decreased with increasing TA support but increased for White and Asian students (Figure 2). And, while attention among all students decreased with increasing TA-student interactions, the effect was more pronounced for international students than for U.S. citizens and permanent residents (Figure 3).

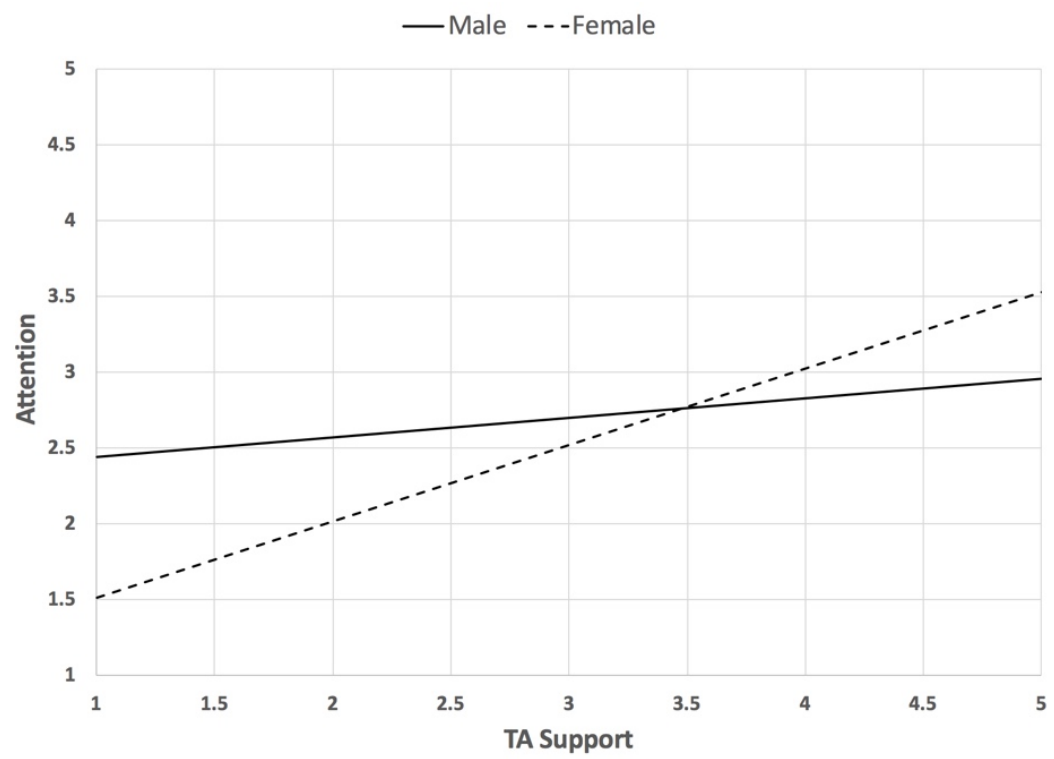

Figure 1: Interactions between Gender and TA support for Attention

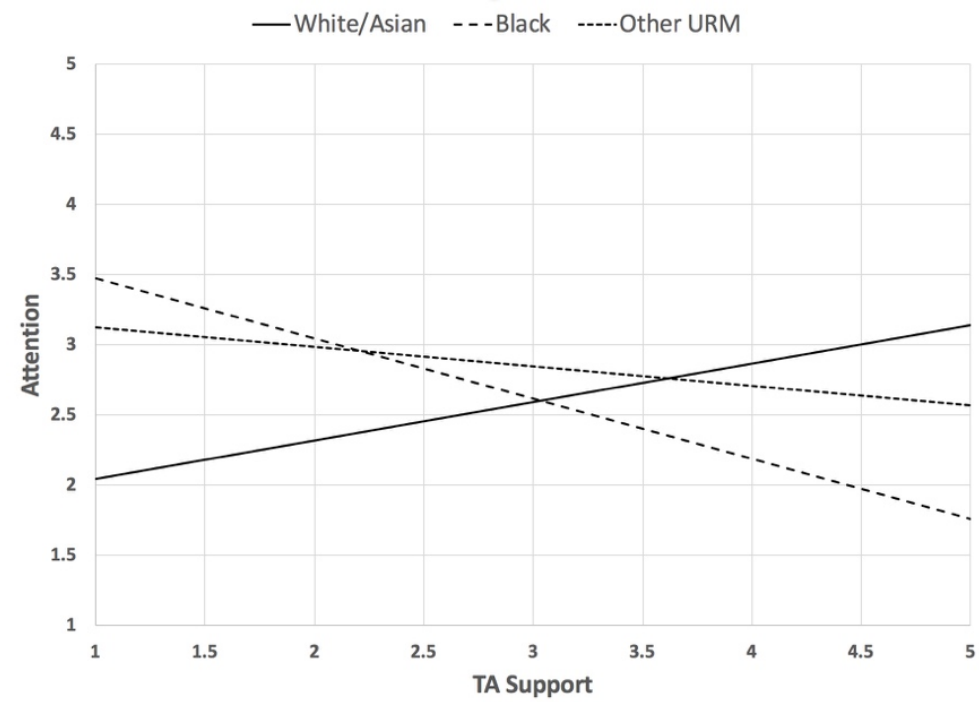

Figure 2: Interactions between Race and TA support for Attention 




Figure 3: Interactions between U.S. Status and TA-student interactions for Attention

Table 7: Hierarchical Regression Models for Attention

\begin{tabular}{|c|c|c|c|c|c|c|c|c|c|}
\hline \multirow[t]{2}{*}{ Predictor Variable } & \multicolumn{3}{|c|}{ Level 1} & \multicolumn{3}{|c|}{ Level 2} & \multicolumn{3}{|c|}{ Level 3} \\
\hline & $\mathrm{B}(\mathrm{SE})$ & $p$ & & B (SE) & $p$ & & $\mathrm{~B}(\mathrm{SE})$ & $p$ & \\
\hline Constant & $2.94(0.11)$ & 0.000 & $* * *$ & $2.58(0.24)$ & 0.000 & $* * *$ & $3.62(0.50)$ & 0.000 & $* * *$ \\
\hline Gender & $0.00(0.05)$ & 0.968 & & $-0.01(0.05)$ & 0.794 & & $-0.00(0.05)$ & 0.949 & \\
\hline Race (Black) & $0.06(0.17)$ & 0.739 & & $0.08(0.17)$ & 0.654 & & $0.24(0.18)$ & 0.176 & \\
\hline Race (other URM) & $-0.02(0.12)$ & 0.867 & & $-0.03(0.12)$ & 0.807 & & $-0.12(0.13)$ & 0.359 & \\
\hline Family income (high) & $-0.12(0.06)$ & 0.066 & & $-0.10(0.06)$ & 0.102 & & $-0.09(0.06)$ & 0.139 & \\
\hline Family income (low) & $-0.01(0.08)$ & 0.935 & & $-0.01(0.08)$ & 0.859 & & $-0.03(0.07)$ & 0.647 & \\
\hline Mother (no degree) & $-0.05(0.07)$ & 0.464 & & $-0.05(0.07)$ & 0.490 & & $-0.04(0.07)$ & 0.519 & \\
\hline Mother (grad degree) & $0.00(0.07)$ & 0.962 & & $0.00(0.07)$ & 0.950 & & $-0.02(0.07)$ & 0.716 & \\
\hline U.S. status & $0.14(0.06)$ & 0.010 & $*$ & $0.17(0.06)$ & 0.004 & $* *$ & $0.20(0.06)$ & 0.001 & $* *$ \\
\hline Transfer status & $0.10(0.05)$ & 0.043 & * & $0.09(0.05)$ & 0.066 & & $-0.25(0.06)$ & 0.076 & \\
\hline TA support & & & & $0.19(0.06)$ & 0.001 & $* *$ & $-0.05(0.13)$ & 0.718 & \\
\hline $\begin{array}{l}\text { TA-student } \\
\text { interactions }\end{array}$ & & & & $-0.02(0.05)$ & 0.000 & $* * *$ & $-0.25(0.06)$ & 0.000 & $* * *$ \\
\hline $\begin{array}{l}\text { Gender } \mathrm{X} \\
\quad \text { TA support }\end{array}$ & & & & & & & $0.12(0.05)$ & 0.012 & $*$ \\
\hline $\begin{array}{c}\text { Race (Black) } \mathrm{X} \\
\text { TA support }\end{array}$ & & & & & & & $-0.29(0.10)$ & 0.004 & $* *$ \\
\hline $\begin{array}{l}\text { U.S. status X } \\
\text { TA-student } \\
\text { interactions }\end{array}$ & & & & & & & $-0.14(0.05)$ & 0.003 & $* *$ \\
\hline
\end{tabular}




\section{Effort}

Regression results for effort are summarized in Table 8. Being Black or another under-represented racial/ethnic minority student initially predicted effort as did being a transfer student. However, the significance of this relationship disappeared when TA support and TA-student interactions were taken into account. No other demographic variables significantly predicted effort in any of the models, but both TA support $(\mathrm{p}<0.001)$ and TA-student interactions $(\mathrm{p}<0.05)$ significantly and positively predicted effort. The more support from and interactions with TAs that students had, the more effort they put forth.

Only one interaction remained significant in the process of iteratively reducing the model. As a result of the reduction, the BIC decreased to -234 (only one interaction considered) from -138 when all 18 interactions were considered and -229 when no interactions were considered. In the final model, interactions between U.S. status and TA support were significant. The association between effort and TA support was more positive for international students than for U.S. citizens and permanent residents (Figure 4).

Table 8: Hierarchical Regression Models for Effort

\begin{tabular}{|c|c|c|c|c|c|c|c|c|c|}
\hline \multirow[t]{2}{*}{ Predictor Variable } & \multicolumn{3}{|c|}{ Level 1} & \multicolumn{3}{|c|}{ Level 2} & \multicolumn{3}{|c|}{ Level 3} \\
\hline & $\mathrm{B}(\mathrm{SE})$ & $p$ & & $\mathrm{~B}(\mathrm{SE})$ & $p$ & & $\mathrm{~B}(\mathrm{SE})$ & $p$ & \\
\hline Constant & $3.98(0.09)$ & 0.000 & $* * *$ & $2.74(0.19)$ & 0.000 & $* * *$ & $2.27(0.24)$ & 0.000 & $* * *$ \\
\hline Gender & $0.01(0.04)$ & 0.782 & & $0.02(0.04)$ & 0.588 & & $0.02(0.04)$ & 0.617 & \\
\hline Race (Black) & $0.33(0.14)$ & 0.023 & $*$ & $0.23(0.14)$ & 0.100 & & $0.25(0.14)$ & 0.076 & \\
\hline Race (other URM) & $-0.23(0.10)$ & 0.024 & $*$ & $-0.19(0.10)$ & 0.054 & & $-0.20(0.10)$ & 0.041 & $*$ \\
\hline Family income (high) & $-0.05(0.05)$ & 0.331 & & $-0.06(0.05)$ & 0.239 & & $-0.06(0.05)$ & 0.221 & \\
\hline Family income (low) & $0.06(0.06)$ & 0.382 & & $0.04(0.06)$ & 0.475 & & $0.05(0.06)$ & 0.452 & \\
\hline Mother (no degree) & $-0.07(0.06)$ & 0.262 & & $-0.05(0.06)$ & 0.370 & & $-0.04(0.06)$ & 0.443 & \\
\hline Mother (grad degree) & $0.03(0.06)$ & 0.588 & & $0.01(0.05)$ & 0.907 & & $0.01(0.05)$ & 0.857 & \\
\hline U.S. status & $-0.01(0.05)$ & 0.878 & & $-0.08(0.05)$ & 0.084 & & $-0.11(0.05)$ & 0.016 & $*$ \\
\hline Transfer status & $0.09(0.04)$ & 0.029 & $*$ & $0.04(0.04)$ & 0.347 & & $0.05(0.04)$ & 0.220 & \\
\hline TA support & & & & $0.28(0.04)$ & 0.000 & $* * *$ & $0.41(0.06)$ & 0.000 & $* * *$ \\
\hline $\begin{array}{l}\text { TA-student } \\
\text { interactions }\end{array}$ & & & & $0.09(0.04)$ & 0.026 & $*$ & $0.08(0.04)$ & 0.066 & \\
\hline $\begin{array}{l}\text { U.S. status X } \\
\text { TA support }\end{array}$ & & & & & & & $0.15(0.05)$ & 0.001 & $* *$ \\
\hline
\end{tabular}




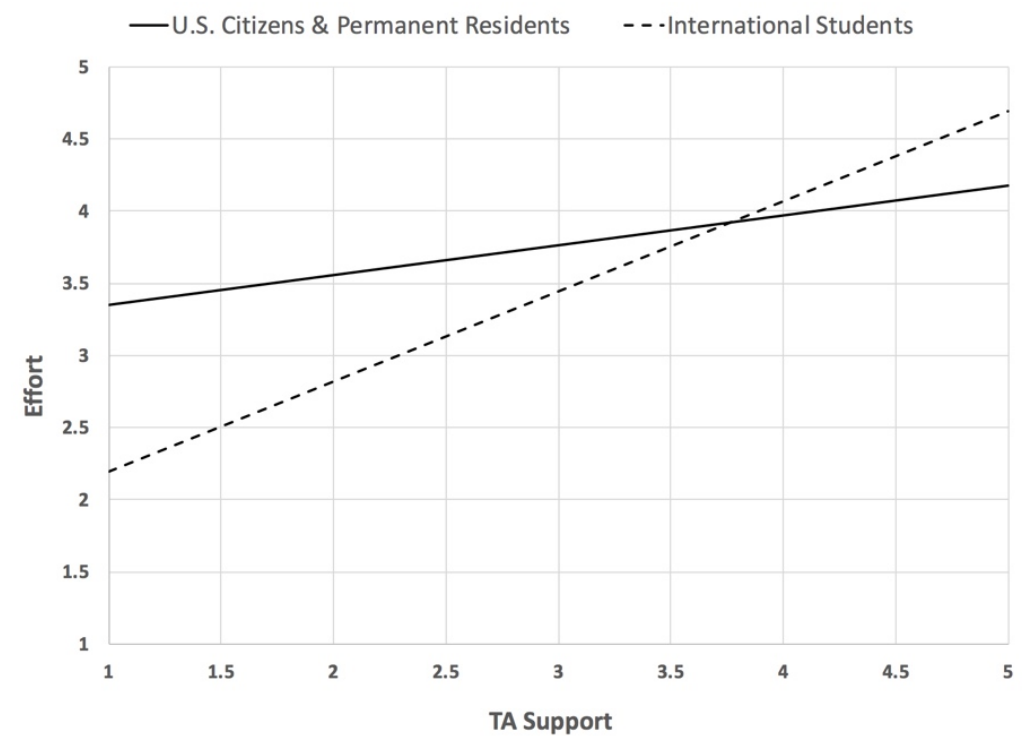

Figure 4: Interactions between U.S. Status and $\boldsymbol{T A}$ support for Effort

\section{Participation}

Results for the last regression model evaluated participation. Results for the reduced model are summarized in Table 9.

Table 9: Hierarchical Regression Models for Participation

\begin{tabular}{|c|c|c|c|c|c|c|c|c|c|}
\hline \multirow[t]{2}{*}{ Predictor Variable } & \multicolumn{3}{|c|}{ Level 1} & \multicolumn{3}{|c|}{ Level 2} & \multicolumn{3}{|c|}{ Level 3} \\
\hline & $\mathrm{B}(\mathrm{SE})$ & $p$ & & $\mathrm{~B}(\mathrm{SE})$ & $p$ & & $\mathrm{~B}(\mathrm{SE})$ & $p$ & \\
\hline Constant & $3.55(0.11)$ & 0.000 & $* * *$ & $1.12(0.20)$ & 0.000 & $* * *$ & $1.27(0.21)$ & 0.000 & $* * *$ \\
\hline Gender & $-0.04(0.05)$ & 0.398 & & $-0.02(0.04)$ & 0.556 & & $-0.02(0.04)$ & 0.540 & \\
\hline Race (Black) & $0.37(0.17)$ & 0.031 & * & $0.18(0.15)$ & 0.235 & & $0.21(0.51)$ & 0.169 & \\
\hline Race (other URM) & $-0.15(0.12)$ & 0.231 & & $-0.07(0.11)$ & 0.505 & & $-0.09(0.11)$ & 0.388 & \\
\hline Family Income (high) & $-0.07(0.06)$ & 0.254 & & $-0.09(0.05)$ & 0.089 & & $-0.09(0.05)$ & 0.081 & \\
\hline Family Income (low) & $0.12(0.08)$ & 0.117 & & $0.10(0.07)$ & 0.133 & & $0.09(0.07)$ & 0.157 & \\
\hline Mother (no degree) & $-0.13(0.07)$ & 0.068 & $*$ & $-0.09(0.06)$ & 0.124 & & $-0.09(0.06)$ & 0.113 & \\
\hline Mother (grad degree) & $-0.15(0.07)$ & 0.024 & & $0.10(0.06)$ & 0.085 & & $0.10(0.06)$ & 0.086 & \\
\hline U.S. status & $0.14(0.06)$ & 0.011 & $* *$ & $0.00(0.05)$ & 0.983 & & $-0.01(0.05)$ & 0.848 & \\
\hline Transfer status & $0.11(0.05)$ & 0.017 & $*$ & $0.01(0.04)$ & 0.850 & & $0.01(0.04)$ & 0.783 & \\
\hline TA support & & & & $0.54(0.05)$ & 0.000 & $* * *$ & $0.50(0.05)$ & 0.000 & $* * *$ \\
\hline $\begin{array}{l}\text { TA-student } \\
\text { interactions }\end{array}$ & & & & $0.18(0.04)$ & 0.000 & $* * *$ & $0.17(0.04)$ & 0.000 & $* *$ \\
\hline $\begin{array}{l}\text { Mother (no degree) X } \\
\text { TA support }\end{array}$ & & & & & & & $-0.11(0.04)$ & 0.014 & $*$ \\
\hline & & $p<$ & 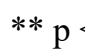 & $01 ; * *$ & 0.001 & & & & \\
\hline
\end{tabular}


In this model, being an international student (U.S. status), being Black and being a transfer student both positively and significantly predicted participation, while having a mother with no degree negatively predicted participation. However, when TA support and TA-student interactions were introduced to the model, these effects disappeared. As with the other models (attention, effort), TA support significantly and positively predicted participation. And, as was the case with effort, TA-student interactions also significantly and positively predicted participation.

Only one interaction remained significant in the process of iteratively reducing the model. As a result of the reduction, the BIC decreased to -157 (only one interaction considered) from -55 when all 18 interactions were considered. Interactions between mother's education (i.e. mother had no college degree) and TA support were significant and the nature of those interactions is shown in greater detail in Figure 5. The participation reported by students whose mother had a college degree increased more with increasing TA support than for students whose mother had no college degree. Further, students whose mother had a degree but perceived low levels of TA support reported less participation than their peers whose mother had no degree. However, the opposite was true at higher levels of TA support -- students whose mother had a degree reported higher levels of participation than those students whose mother did not have a degree.



Figure 5: Interactions between Mother's Education and $\boldsymbol{T A}$ support for Participation

\section{Discussion}

Both TA support and TA-student interactions were consistently and significantly associated with all three forms of engagement, although the nature of this relationship was not always positive. Interactions with particular demographic groups also emerged and merit further investigation. 
Research Question \#1 (RQ1):

Are TA support and TA-student interactions significantly related to student engagement?

The regression results suggested that much of what TAs do is strongly connected to engagement among all students, regardless of demographics. Both TA support and TA-student interactions were significantly associated with all three forms of engagement. With the exception of attention and TA-student interactions, all of these relationships were significant and positive. And, the relationships between $T A$ support and the three engagement measures were consistently stronger than those for TA-student interactions.

The significant and positive associations between TA support and engagement indicated that students who paid more attention, participated more, and put forth more effort overall in both lecture and lab/discussion sections felt that their TA was organized, used good examples, engaged students during class, and demonstrated care and interest in student learning. Consistent with Umbach \& Wawryzynski's (2005) study of faculty support and engagement among over 40,000 undergraduates, these results suggest that these course-related TA behaviors play an important role in student engagement across the board. In Umbach \& Wawryzynski's study, course-related interactions with faculty and faculty support for learning were significantly related to engagement as measured by time on task and investment in certain academic activities such as hours spent preparing for class and number of papers written. In this study, the relationships between instructor support and student engagement extended to TA practices as well, thereby demonstrating the importance of all instructors in making meaningful contributions to student engagement.

TA-student interactions were also significantly associated with all three forms of engagement. As with TA support, these findings mirror other studies of faculty contributions to engagement that illustrated the importance of quality faculty-student interaction (Bjorklund et al., 2004; Chen et al., 2008; Heller et al., 2010). Indeed, given that students in engineering and other STEM courses were often more likely to have direct contact with a TA than with a faculty member (Gardner \& Jones, 2011; Rushin et al., 1997) and that students expected their TA to be approachable and accessible (Kendall \& Schussler, 2012), this finding is especially relevant for understanding engagement in this setting.

Despite the importance of TA-student interactions in the regression models, the relationships between TA-student interactions and attention $(\mathrm{B}=-0.02)$, effort $(\mathrm{B}=0.09)$, and participation ( $\mathrm{B}$ $=0.18)$ were not as strong as for TA support and attention $(\mathrm{B}=0.19)$, effort $(\mathrm{B}=0.28)$, and participation $(\mathrm{B}=0.54)$. The TA-student interactions scale in this study included both courserelated interactions and interactions unrelated to the course. In contrast, the TA support measure included only course-related measures. Umbach \& Wawryzynski's study (2005) also found that among faculty, out-of-class interactions with faculty had less of an effect on student engagement than within-class interactions and practices, which reinforces the similarities between how interactions with faculty and TAs impact student engagement.

Interestingly, although TA-student interactions positively predicted effort and participation, these interactions negatively and significantly predicted attention. In other words, students who reported higher levels of contact with their TA also tended to report lower levels of in-class attention. Closer examination of this relationship (Figure 6) suggests that this negative effect is most evident 
among students who have frequent interactions with TAs.

It is possible that some students may seek out interaction with their TAs because they are interested and engaged, while others seek out interaction because they are struggling with course material, which could be a cause or result of decreased attention in class. Indeed, another study of engineering and other STEM students identified a similar issue with student-instructor interaction patterns, finding that students who were struggling academically or who had received negative feedback from faculty about their work reported more frequent interaction with their professors (Hurtado et al., 2011). It stands to reason that students who are struggling academically may find it difficult to keep up and pay attention in class and may turn to interactions with instructors, especially TAs, outside of class to compensate.

The results of this study support that TA support and TA-student interactions are closely associated with student engagement. While these results held true for all students, regardless of demographics, our models also showed that some relationships between TA support and TAstudent interactions and student engagement measures played out in unique ways for particular groups of students. These findings are discussed next.

Research Question \#2 (RQ2):

\section{Do different students appear to respond to TA support and TA-student interactions differently?}

While some aspects of TA teaching clearly matter for all students, our results point toward some variation in these relationships among different student groups. Tinto's (1986) theory supports this, stating that student integration arises from dynamic interplay between individual student characteristics (e.g. gender, race, educational background) and institutional characteristics (e.g. instructor teaching styles). The following section discusses results which were not generalizable to all students but were true for certain demographic groups.

Gender: TA support positively predicted attention more strongly for women than for men (Figure 1a), although no significant interactions between gender and effort or participation emerged from the regression models. As numerical minorities in engineering, female students face a number of potential stressors including but not limited to the experience of stereotype threat (Murphy et al., 2007; Steele, 1997), a lower sense of belonging (Lewis et al., 2017) and lower perceptions of support for question-asking in comparison with male peers (Haskett et al., 2017). As a result of these barriers, women may respond more strongly to TA support than men do. The level of attention among women in the present study certainly appears to confirm this hypothesis. Of students who report low levels of TA support, women pay less attention than men, but of those experiencing high levels of TA support, women respond more strongly than men by paying far more attention. Strong TA support may function as a buffer against the risk women in engineering face with potentially more negative experiences in their courses compared to male peers. Indeed, academic integration - including positive contact with instructors - is highly important for female student academic success in engineering (Kamphorst et al., 2015). The present study extends this relationship to include the influence of TAs as well as faculty.

International Students: TA-student interactions negatively predicted attention, and more so for international students than for U.S. citizens and permanent residents (Figure 3). International 
students often experienced feelings of inferiority in their primary classrooms due to their English language ability (J. Kim, 2012) and perceived that American faculty think less of them than their American peers (Valdez, 2015). Furthermore, international students and non-White students had more positive views of international teaching assistants (Neves \& Sanyal, 1991) than White, U.S.born students did. In this study, a large majority of the international students were Asian, a majority of faculty were White and U.S. citizens, and a majority of TAs were Asian, many of them international. It stands to reason, then, that international students who struggled in the classroom to be accepted and understand what a professor is saying may turn to international TAs from similar Asian cultures to compensate for reduced ability or desire to pay attention in the primary classroom. When such TAs are perceived as more supportive, these students were also likely to put forth more effort (Figure 4).

Race: Interestingly, Black students paid less attention when they report greater TA support (Figure 2); other under-represented minority students also exhibited this trend, although the interaction is not statistically significant in the regression models. In a large, quantitative study of undergraduates at 10 University of California campuses, Kim \& Lundberg (2016) found that the benefits of faculty-student interaction for outcomes including classroom engagement, cognitive gains and sense of belonging were moderated by race/ethnicity, with minority students experiencing lower levels of faculty-student interaction and reaping fewer of the benefits thereof. Our findings should be interpreted with some caution given the small number of Black students in the sample $(3.5 \%$ of the total sample size), but these findings suggest that similar to international students, Black students may be compensating for perceived disparities in the classroom and lower support from faculty by turning to TAs when strong TA support is available. Alternatively, when strong TA support is available, these students may be finding less need to pay attention.

Mother's Education: The results of this study found that TA support more strongly predicted participation for students whose mother had a college degree compared to those students whose mother did not (Figure 5). Given the high correlation between the mother's education and father's education among participants in this study (Pearson's correlation $=0.608, p<0.01$ ), it is reasonable to presume that most students who reported their mother having no college degree were firstgeneration college students (i.e. neither mother or father had a college degree). The weaker relationship between TA support and participation for first-generation students is consistent with the mismatch between the norms of independence of the American university and the norms of interdependence that dominate the working class (Stephens et al., 2012) which limit the benefits first-generation students can reap from both faculty and TAs. Other research has also established that first-generation students have lower academic engagement than continuing-generation students as measured by student-faculty interactions and participation in class than their continuing-generation peers (Soria \& Stebleton, 2012). However, in this study, students whose mothers had no degree report higher levels of engagement (as measured by participation) than continuing-generation students when they perceive that TA support is low. A possible explanation for this anomalous result may be that since first-generation students are less integrated academically and struggle to fit in given their relative lack of culture capital (Spengen, 2013), they may be less responsive than their peers to anomalous levels of instructional support. This possibility merits further study. 


\section{Limitations and Implications}

Limitations: This study was limited to seven engineering courses at a single institution. Thus, we cannot claim that our findings are generalizable to other engineering courses at other institutions. But, evaluated in the context of the broader research on engagement and instructional support, our study reinforces the importance of the TA in the student's life and offers insight into how TA behaviors may be perceived and processed differently from faculty support. Another limitation of this study is that the collected data are cross-sectional in nature and cannot prove cause and effect. However, an argument can be made that, within a single term and course, what TAs do is more likely to influence student engagement than student engagement is to influence what TAs do.

Implications: This study has reinforced the notion that TAs have tremendous potential to improve student engagement in undergraduate engineering courses. Whether this potential is realized depends on the degree to which TAs are equipped with pedagogical tools for promoting engagement among their students. Gaining a greater understanding of the types of support that TAs offer to students and how such support is related to student engagement and other outcomes is essential for developing effective and efficient professional development and training for these novice teachers. This study reinforces the need for strong TA professional development as well as implementing course- and department-level practices which influence the degree to which TAs are supported in their teaching roles.

\section{Concluding Remarks}

This study underscores the importance of TAs in the engineering classroom, both in the support they provide and the interactions they have with students. In combination with other related studies, the results presented here support the fact that institutions seeking to enhance student engagement should approach the task with the assumption that teaching is not a one-size-fits-all endeavor. Strategies that reach one audience may not reach all. Demographics matter. Therefore, TAs should be equipped with tools for "temperature checks" in their classes (e.g. midterm evaluations, periodic student reflections) to identify when the engagement needs of some students may be going unmet. This, coupled with a more robust, varied toolkit of engagement strategies, may enable TAs to bolster the engagement of all students at multiple levels.

\section{Acknowledgements}

The author would like to gratefully acknowledge the National Science Foundation for their support of this work (DUE grant number 1504618). Any opinions, findings, and conclusions or recommendations expressed in this material are those of the author(s) and do not necessarily reflect the views of the National Science Foundation. The author would also like to thank the statistical consulting resources provided by the Center for Statistics and the Social Sciences, University of Washington. 


\section{Funding}

The author(s) disclosed receipt of the following financial support for the research, authorship, and/or publication of this article: This work was supported by the National Science Foundation (DUE grant number 1504618).

\section{Conflicts of interest:}

The Authors declare that there is no conflict of interest.

\section{References}

Bjorklund, S. A., Parente, J. M., \& Sathianathan, D. (2004). Effects of faculty interaction and feedback on gains in student skills. Journal of Engineering Education, 93(2), 153-160.

Bureau of Labor Statistics, B. (n.d.). Graduate Teaching Assistants. Occupational Employment Statistics, May 2018: Graduate Teaching Assistants. Retrieved May 30, 2019, from https://www.bls.gov/oes/current/oes251191.htm\#(3)

Carini, R. M., Kuh, G. D., \& Klein, S. P. (2006). Student Engagement and Student Learning: Testing the Linkages. Research in Higher Education, 47(1), 1-32. https://doi.org/10.1007/s11162-005-8150-9

Carnegie Foundation. (2018). 2018 Classification Update. http://carnegieclassifications.iu.edu/

Chen, H. L., Lattuca, L. R., \& Hamilton, E. R. (2008). Conceptualizing engagement: Contributions of faculty to student engagement in engineering. Journal of Engineering Education, 97(3), 339-353.

Chickering, A., \& Gamzon, Z. F. (1987). Seven principles for good practice in undergraduate education. AAHE Bulletin, 3, 3-7.

Connell, J. P., \& Wellborn, J. G. (1991). Competence, autonomy, and relatedness: A motivational analysis of self-system processes. In Self processes and development (pp. 4377). Lawrence Erlbaum Associates, Inc.

Deci, E. L., Vallerand, R. J., Pelletier, L. G., \& Ryan, R. M. (1991). Motivation and education: The self-determination perspective. Educational Psychologist, 26(3-4), 325-346.

Einarson, M. K., \& Clarkberg, M. E. (2010). Race Differences in the Impact of Students' Out-ofClass Interactions with Faculty. Journal of the Professoriate, 3(2).

Felder, R. M. (2000). The Future of Engineering Education. 34(1), 26-39.

Gardner, G. E., \& Jones, M. G. (2011). Pedagogical preparation of the science graduate teaching assistant: Challenges and implications. Science Educator, 20(2), 31-41.

Gellin, A. (2003). The effect of undergraduate student involvement on critical thinking: A metaanalysis of the literature 1991-2000. Journal of College Student Development, 44(6), 746762. 
George, D., \& Mallery, P. (2010). SPSS for Windows Step by Step: A simple guide and reference. Pearson.

Good, J., Colthorpe, K., Zimbardi, K., \& Kafer, G. (2015). Research and Teaching: The Roles of Mentoring and Motivation in Student Teaching Assistant Interactions and in Improving Experience in First-Year Biology Laboratory Classes. Journal of College Science Teaching, 44(4), n4.

Handelsman, M. M., Briggs, W. L., Sullivan, N., \& Towler, A. (2005). A Measure of College Student Course Engagement. The Journal of Educational Research, 98(3), 184-192. https://doi.org/10.3200/JOER.98.3.184-192

Haskett, D., Student, G. S., \& Hilpert, J. C. (2017). Gender and Ethnic Differences in Classroom Engagement and Knowledge Building in Engineering Energy Science Courses.

Hazari, Z., Key, A. W., \& Pitre, J. (2003). Interactive and affective behaviors of teaching assistants in a first year physics laboratory. Electronic Journal of Science Education, 7(3).

Heller, R. S., Beil, C., Dam, K., \& Haerum, B. (2010). Student and faculty perceptions of engagement in engineering. Journal of Engineering Education, 99(3), 253-261.

Hughes, R., \& Pace, C. R. (2003). Using NSSE to study student retention and withdrawal. Assessment Update, 15(4), 1-2.

Hurtado, S., Eagan, M. K., Tran, M. C., Newman, C. B., Chang, M. J., \& Velasco, P. (2011). "We do science here": Underrepresented students' interactions with faculty in different college contexts. Journal of Social Issues, 67(3), 553-579.

Kamphorst, J. C., Adriaan Hofman, W. H., Jansen, E. P., \& Terlouw, C. (2015). Explaining academic success in engineering degree programs: Do female and male students differ? Journal of Engineering Education, 104(2), 189-211.

Kendall, K. D., \& Schussler, E. E. (2012). Does Instructor Type Matter? Undergraduate Student Perception of Graduate Teaching Assistants and Professors. CBE Life Sciences Education, 11(2), 187-199. https://doi.org/10.1187/cbe.11-10-0091

Kim, J. (2012). The birth of academic subalterns: How do foreign students embody the global hegemony of American universities? Journal of Studies in International Education, 16(5), $455-476$.

Kim, Y. K., \& Lundberg, C. A. (2016). A structural model of the relationship between studentfaculty interaction and cognitive skills development among college students. Research in Higher Education, 57(3), 288-309.

Kuh, G. D. (2009). What student affairs professionals need to know about student engagement. Journal of College Student Development, 50(6), 683-706.

Kuh, G. D., Cruce, T. M., Shoup, R., Kinzie, J., \& Gonyea, R. M. (2008). Unmasking the Effects of Student Engagement on First-Year College Grades and Persistence. The Journal of Higher Education, 79(5), 540-563. JSTOR.

Lewis, K. L., Stout, J. G., Finkelstein, N. D., Pollock, S. J., Miyake, A., Cohen, G. L., \& Ito, T. A. (2017). Fitting in to move forward: Belonging, gender, and persistence in the physical 
sciences, technology, engineering, and mathematics (pSTEM). Psychology of Women Quarterly, 41(4), 420-436.

Miserandino, M. (1996). Children who do well in school: Individual differences in perceived competence and autonomy in above-average children. Journal of Educational Psychology, 88(2), 203-214. https://doi.org/10.1037/0022-0663.88.2.203

Murphy, M. C., Steele, C. M., \& Gross, J. J. (2007). Signaling Threat: How Situational Cues Affect Women in Math, Science, and Engineering Settings. Psychological Science, 18(10), 879-885. https://doi.org/10.1111/j.1467-9280.2007.01995.x

National Survey of Student Engagement, (NSSE). (2019). NSSE Engagement Indicators. $\mathrm{http}: / /$ nsse.indiana.edu/html/engagement_indicators.cfm

Neves, J. S., \& Sanyal, R. N. (1991). Classroom communication and teaching effectiveness: The foreign-born instructor. Journal of Education for Business, 66(5), 304-308.

O’Neal, C., Wright, M., Cook, C., Perorazio, T., \& Purkiss, J. (2007). The impact of teaching assistants on student retention in the sciences: Lessons for TA training. Journal of College Science Teaching, 36(5), 24.

Pike, G. R., \& Killian, T. S. (2001). Reported Gains in Student Learning: Do Academic Disciplines Make a Difference? Research in Higher Education, 42(4), 429-454. https://doi.org/10.1023/A:1011054825704

Prieto, L. R., \& Altmaier, E. M. (1994). The relationship of prior training and previous teaching... - Google Scholar. Research in HIgher Education, 35(4), 481-497.

Reeves, T. D., Marbach-Ad, G., Miller, K. R., Ridgway, J., Gardner, G. E., Schussler, E. E., \& Wischusen, E. W. (2016). A conceptual framework for graduate teaching assistant professional development evaluation and research. CBE-Life Sciences Education, 15(2), es2.

Robbins, S. B., Huy Le, Davis, D., Carlstrom, A., Lauver, K., \& Langley, R. (2004). Do Psychosocial and Study Skill Factors Predict College Outcomes? A Meta-Analysis. Psychological Bulletin, 130(2), 261-288. https://doi.org/10.1037/0033-2909.130.2.261

Rushin, J. W., Saix, J. D., Lumsden, A., Streubel, D. P., Summers, G., \& Bernson, C. (1997). Graduate Teaching Assistant Training: A Basis for Improvement of College Biology Teaching \& Faculty Development? The American Biology Teacher, 59(2), 86-90. https://doi.org/10.2307/4450255

Scherr, R. E., Russ, R. S., Bing, T. J., \& Hodges, R. A. (2006). Initiation of student-TA interactions in tutorials. Physical Review Special Topics - Physics Education Research, 2(2), 020108. https://doi.org/10.1103/PhysRevSTPER.2.020108

Seymour, E., \& Hewitt, N. (2000). Talking about Leaving: Why Undergraduates Leave the Sciences. Westview Press.

Shannon, D. M., Twale, D. J., \& Moore, M. S. (1998). TA teaching effectiveness: The impact of training and teaching experience. The Journal of Higher Education, 69(4), 440-466. 
Soria, K. M., \& Stebleton, M. J. (2012). First-generation students' academic engagement and retention. Teaching in Higher Education, 17(6), 673-685.

https://doi.org/10.1080/13562517.2012.666735

Spengen, A. E. (2013). The Experiences of First-Generation University Students. Western University Sociology Publications, 32, 9.

Steele, C. M. (1997). A threat in the air. How stereotypes shape intellectual identity and performance. The American Psychologist, 52(6), 613-629.

Stephens, N. M., Fryberg, S. A., Markus, H. R., Johnson, C. S., \& Covarrubias, R. (2012). Unseen disadvantage: How American universities' focus on independence undermines the academic performance of first-generation college students. Journal of Personality and Social Psychology, 102(6), 1178.

Tinto, V. (1986). Theories of student departure revisited. In Higher education: Handbook of theory and research (pp. 359-384).

Tinto, V. (1993). Leaving college: Rethinking the causes and cures of student attrition. University of Chicago Press.

Trenshaw, K. F., Revelo, R. A., Earl, K. A., \& Herman, G. L. (2016). Using self-determination theory principles to promote engineering students' intrinsic motivation to learn. International Journal of Engineering Education, 32(3), 1194-1207.

Umbach, P. D. (2007). How Effective Are They? Exploring the Impact of Contingent Faculty on Undergraduate Education. Review of Higher Education, 30(2), 91-123.

Umbach, P. D., \& Wawrzynski, M. R. (2005). Faculty do matter: The role of college faculty in student learning and engagement. Research in Higher Education, 46(2), 153-184.

Valdez, G. (2015). US Higher Education Classroom Experiences of Undergraduate Chinese International Students. Journal of International Students, 5(2), 188-200.

Van Ryzin, M. J., Gravely, A. A., \& Roseth, C. J. (2009). Autonomy, belongingness, and engagement in school as contributors to adolescent psychological well-being. Journal of Youth and Adolescence, 38(1), 1-12.

Wheeler, L. B., Maeng, J. L., Chiu, J. L., \& Bell, R. L. (2017). Do teaching assistants matter? Investigating relationships between teaching assistants and student outcomes in undergraduate science laboratory classes. Journal of Research in Science Teaching, 54(4), 463-492.

Wilson, D., Jones, D., Bocell, F., Crawford, J., Kim, M. J., Veilleux, N., Floyd-Smith, T., Bates, R., \& Plett, M. (2015). Belonging and Academic Engagement Among Undergraduate STEM Students: A Multi-institutional Study. Research in Higher Education, 56(7), 750-776. https://doi.org/10.1007/s11162-015-9367-x

Wolf-Wendel, L., Ward, K., \& Kinzie, J. (2009). A tangled web of terms: The overlap and unique contribution of involvement, engagement, and integration to understanding college student success. Journal of College Student Development, 50(4), 407-428. 
Wright, J., Wilson, D., \& Summers, L. (2019). It's Not Just What TA's Know: Exploring the Role of Teacher Efficacy among Engineering TA's. Proc., ASEE Annual Conference and Exposition: Tampa, Florida. 